\title{
Antimicrobial Potential of Bioactive Metabolites and Silver Nanoparticles from Bacillus spp. and of Some Antibiotics Against Multidrug Resistant Salmonella spp.
}

\author{
Bacillus spp.'nin Biyoaktif Metabolitleri ile Gümüş Nanopartikülleri ve Çoklu \\ İlaç Direncine Karşı Bazı Antibiyotiklerin Antimikrobiyal Potansiyelleri
}

\author{
(D) Bukola Christianah ADEBAYO-TAYO*, (D) Oluwadara EKUNDAYO-OBABA, (D) Olutayo Israel FALODUN
}

Ibadan University, Department of Microbiology, Ibadan, Oyo State, Nigeria

\begin{abstract}
Objectives: The synthesis of nanoparticles using microorganisms and their metabolites is of increasing interest because they are potential producers of biocompatible and environmental friendly nanoparticles. Their nanoparticles can serve as potent alternatives to antibiotics against multidrug resistant (MDR) bacteria. The antibacterial potential of Bacillus spp. metabolites, their silver nanoparticles (SNPs), and some antibiotics against MDR Salmonella spp. was evaluated.

Materials and Methods: The antimicrobial potential of metabolites and SNPs biosynthesized from Bacillus spp. was characterized, the effect of physicochemical parameters on SNP biosynthesis, the antimicrobial activity of the SNPs, and combination of SNPs and antibiotics against MDR Salmonella strains were evaluated.

Results: The bioactive metabolites of the Bacillus spp. exhibited varied antimicrobial potential against the tested MDR Salmonella spp. The metabolites were able to bioreduce silver nitrate $\left(\mathrm{AgNO}_{3}\right)$ to $\mathrm{Ag}+$ for SNP biosynthesis. Change in color from whitish to darkish brown and a surface plasma resonance peak of 600-800 nm were observed. The SNPs were aggregated, rods, and crystalline in shape and their sizes were $15 \mu \mathrm{m}, 16 \mu \mathrm{m}$, and $13 \mu \mathrm{m}$. Carboxylic acid, amino acid, alcohol, esters, and aldehydes were the functional groups found in the biosynthesized SNPs. The antibacterial activity of BAC1-SNPs, BAC7-SNPs, and BAC20-SNPs against MDR Staphylococcus aureus 9 (MDRSA9) and MDRSA18 was 6.0-22 mm and 11-20 $\mathrm{mm}$. SNPs biosynthesized at $\mathrm{pH} 7$ and $10 \mathrm{mM} \mathrm{AgNO}_{3}$ had the highest antagonistic activity. Combination of SNPs and antibiotics exhibited the best antagonistic potential.

Conclusion: The metabolites and SNPs from Bacillus spp. exhibited antagonistic effects against MDR Salmonella spp. The combined SNPs and antibiotics had better antimicrobial activity.
\end{abstract}

Key words: Bacillus strains, metabolites, antimicrobial, silver nanoparticles, MDR Salmonella species, synergistic effect

öz

Amaç: Biyouyumlu ve çevre dostu nanopartiküllerin potansiyel üreticileri olan mikroorganizmalar ve bunların metabolitleri kullanılarak hazırlanan nanopartiküllere olan ilgi son yıllarda artmıştır. Bu nanopartiküller, çoklu ilaç direnci (MDR) olan bakterilere karşı antibiyotiklere güçlü alternatifler olarak değerlendirilebilir. Bacillus spp. metabolitlerinin, bunların gümüş nanopartiküllerinin (SNP) ve MDR Salmonella spp'ye karşı bazı antibiyotiklerin antibakteriyel potansiyelleri değerlendirildi.

Gereç ve Yöntemler: Bacillus spp.'den biyosentezlenen metabolitlerin ve SNP'lerin antimikrobiyal etki potansiyelleri, fizikokimyasal parametrelerin SNP biyosentezine etkileri, SNP'lerin antimikrobiyal aktivitesi ve SNP'ler ile kombine edilen antibiyotiklerin MDR Salmonella suşlarına karșı etkileri değerlendirildi.

Bulgular: Bacillus türlerinin biyoaktif metabolitleri test edilen MDR Salmonella spp.'ye karşı değişken antimikrobiyal aktivite gösterdiler. Metabolitler, SNP biyosentezi için gümüş nitratı $\left(\mathrm{AgNO}_{3}\right) \mathrm{Ag}+$ 'ya biyolojik olarak indirgeyebilmiştir. Beyazımsıdan koyu kahverengiye renk değişimi ve yüzey

*Correspondence: E-mail: bukola.tayo@gmail.com, Phone: +234 8035522409 ORCID-ID: orcid.org/0000-0003-2404-1686

Received: 08.07.2019, Accepted: 05.09.2019

-Turk J Pharm Sci, Published by Galenos Publishing House. 
plazmon rezonans spektroskopisinde 600-800 nm'de bir pik gözlendi. Agrege olan SNP'lerin, çubuk ve kristal şeklinde oldukları; boyutlarının 15 $\mu \mathrm{m}, 16 \mu \mathrm{m}$ ve $13 \mu \mathrm{m}$ olduğu tespit edilmiștir. Karboksilik asit, amino asit, alkol, ester ve aldehit, biyosentezlenmiş SNP'lerde bulunan fonksiyonel gruplardır. BAC1-SNP'lerin, BAC7-SNP'lerin ve BAC20-SNP'lerin MDRSA9 ve MDRSA18'e karşı gösterdikleri antibakteriyel aktivite sırasıyla 6,0-22 mm ve 11-20 mm aralığındaydı. pH 7 ve $10 \mathrm{mM} \mathrm{AgNO}_{3}$ 'te biyosentezlenen SNP'lerin en yüksek antagonistik aktiviteye sahip olduğu bulundu. En iyi antagonistik potansiyel SNP'lerin ve antibiyotiklerin kombinasyonu ile elde edildi.

Sonuç: Bacillus spp.'den biyosentezlenen metabolitlerin ve SNP'lerin MDR Salmonella spp'ye karşı antagonistik etkileri olduğu bulundu. SNP'ler ile kombine antibiyotiklerin daha iyi antimikrobiyal aktiviteye sahip olduğu tespit edildi.

Anahtar kelimeler: Bacillus sușları, metabolitler, antimikrobiyal, gümüș nanopartiküller, MDR Salmonella türleri, sinerjistik etki

\section{INTRODUCTION}

Infections caused by harmful microorganisms affect many people globally and they are an important cause of morbidity and mortality with adverse effects on the healthcare economy.1.2 The treatment of these infections is of public health concern as a result of development of resistance to antibiotics by these etiological agents. ${ }^{3,4}$

Salmonella, the most commonly isolated food-borne pathogens associated with fresh fruits and vegetables, are Gram-negative flagellated rod-shaped facultative anaerobe bacteria.5,6 Salmonella are a group of bacteria that cause typhoid fever, food poisoning, gastroenteritis, enteric fever, and other illnesses. Salmonella infections, or salmonellosis, are bacterial diseases of the intestinal tract.

The occurrence of enteric fever has been a major health problem in spite of the use of antibiotics and the development of newer antimicrobials. Resistance of Salmonella spp. to previously efficacious drugs like ciprofloxacin, ampicillin, ceftriaxone, and cotrimoxazole has been reported. ${ }^{7}$ Adabara et al. ${ }^{8}$ reported the prevalence and antibiotic susceptibility pattern of Salmonella typhi among patients in a military hospital in Minna, Nigeria. The isolates were resistant to all the antibiotics tested, which are the drugs of choice routinely used in the study area for the treatment of typhoid fever.

Multidrug resistant (MDR) Salmonella strains are very common and are the causative agent of endemic and epidemic typhoid fever infections in many communities. MDR Salmonella typhi poses a serious threat because it has developed resistance to available antibiotics, resulting in an increase in the death rate and high capability for epidemic outbreaks of typhoid that may be difficult to manage.

The consequence of typhoid fever outbreaks may be highly destructive most especially in developing countries where health facilities are very poor. Salmonella has been reported as the most common cause of bacterial food-borne illness in the US and is estimated to annually cause over 1 million cases, 19,000 hospitalizations, 350 deaths, and $\$ 2.6$ billion in social costs. ${ }^{9.10}$ Salmonella enterica serovar typhimurium is one of the most common salmonellae in humans and livestock, and most of these strains are resistant to multiple antibiotics.

Bacillus species are Gram-positive, endospore-forming, chemoheterotrophic rod-shaped bacteria that are usually motile with peritrichous flagella; they are aerobic or facultative anaerobic and catalase positive and part of the phylum Firmicutes. Many Bacillus species are of remarkable importance because they are antibiotic producers. $B$. subtilis, $B$. polymyxa, B. brevis, B. licheniformis, B. circulans, and B. cereus have been reported as antibiotic producers. Antibiotics such as bacitracin, gramycidin S, polymyxin, and tyrotricidin produced by Bacillus spp. have found application in medical treatments.1-14 A wide range of antimicrobial, antiviral, anti-ameobocytic, and antimycoplasma activities of Bacillus species have been reported. .5-17 $^{-17}$

The ability of Bacillus species to produce different metabolites with antimicrobial activity has been extensively used in medicine and the pharmaceutical industry; one of its potentials is its application as a biocontrol agent for animal, human, and plant diseases. ${ }^{18}$

Silver and silver-containing products are among the most popular and efficient antimicrobial agents commonly used against pathogenic bacteria. ${ }^{19}$ Since ancient times silver has been in used as an antimicrobial agent but with the development of antibiotics there has been a reduction in the medical applications of silver as an antimicrobial. ${ }^{20}$

Nanolevel manipulation and physicochemical changes of silver can lead to production of silver nanoparticles (SNPs) with an increase in antimicrobial potential. SNPs are characterized by high surface-area-to-volume ratio and the unique chemical and physical properties that confer on them better antimicrobial properties. ${ }^{21}$

SNPs $0-100 \mathrm{~nm}$ in size showed strong bactericidal potential against both Gram-positive and Gram-negative bacteria. ${ }^{22}$ Silver in the form of SNPs is known to exhibit strong biocidal effects on different bacterial strains, including MDR bacteria. 23,24 SNPs have little chance of drug resistance, which provides a solution to multidrug resistance problems. ${ }^{25}$ Drug resistance has been reported as one of the most serious threatening and widespread problems in all developing countries. ${ }^{26}$ Hence, diverse medical applications of AgNPs are necessary to avoid the effect of these drug-resistant pathogenic microorganisms by various methods, ranging from silver-based dressings and silver-coated medical devices, such as nanogels and nanolotions, to dental materials, sunscreen lotions, biological labeling, water treatment, in optical devices, and as an antibactericidal. ${ }^{27-29}$ Microbial resistance to antimicrobials is highly prevalent worldwide, particularly in developing countries, and this has made therapeutic options appear more limited than ever. As a result of the emergence of MDR pathogens, research interest has been geared towards the development of efficient and safe antimicrobials. For these reasons, the aim of the present research was to investigate the 
antimicrobial potential of metabolites from Bacillus spp., their SNPs, and combination of SNPs with some antibiotics against some selected MDR Salmonella spp.

\section{MATERIALS AND METHODS}

\section{Microorganisms}

Cultures of Bacillus spp. and 10 MDR Salmonella spp. were obtained from the culture collection of our previous work in the Microbial Physiology and Biotechnology Unit, Department of Microbiology, University of Ibadan. The isolates were kept on nutrient agar slants in a refrigerator. Constant subculturing was carried out to ensure the viability of the isolates.

\section{Production of bioactive metabolites from Bacillus strains}

Three Bacillus strains were used for the production of bioactive metabolites using sterile nutrient broth. The supernatant from the sterile inoculated nutrient broth was incubated at $35^{\circ} \mathrm{C}$ for $48 \mathrm{~h}$ and used as bioactive metabolites.

Antagonistic potential of the bioactive metabolites produced by Bacillus spp. against some MDR Salmonella spp.

The antagonistic potential of the bioactive metabolites against some MDR Salmonella spp. was investigated using agar well diffusion. ${ }^{30}$ Inoculum suspensions of 24 -h-old culture of the Salmonella spp. were spread plated on Mueller-Hinton agar. Uniform wells of $6 \mathrm{~mm}$ were bored in the agar. Each well was filled with $60 \mu \mathrm{L}$ of the bioactive metabolites from the Bacillus isolates. The plates were incubated at $37^{\circ} \mathrm{C}$ for $24 \mathrm{~h}$. The incubated plates were observed for a zone of inhibition (ZOI) around the well. The formation of a clear zone around the well is an indication of antibacterial activity. ${ }^{31}$ Results were considered positive if the diameter $(\mathrm{mm})$ of the $\mathrm{ZOI}$ around the well was greater than $1 \mathrm{~mm}$. The bioactive metabolites of the best three Bacillus spp. were used for further studies.

\section{Production of SNPs using the selected Bacillus strains}

The bioactive metabolites of the best three Bacillus spp. were used for the production of SNPs. First $30 \mathrm{~mL}$ of the bioactive metabolites was added to $70 \mathrm{~mL}$ of $10 \mathrm{mM}$ silver nitrate $\left(\mathrm{AgNO}_{3}\right)$ solution. The mixture was stored at room temperature $\left(35^{\circ} \mathrm{C}\right)$ in a dark place for 24-72 h. After $12 \mathrm{~h}$ of incubation, the whitish solution turned brownish, which confirmed the formation of SNPs.

\section{Characterization of the synthesized SNPS}

The SNPs were characterized using visual detection for change in color. Ultraviolet (UV)-Visabsorption (Vis) spectra of the SNPs were analyzed at room temperature using a UVVis spectrophotometer (Lambda 25, PerkinElmer, Waltham, MA, USA) with a resolution of $0.5 \mathrm{~nm}$ at the wavelengths of 200-800 $\mathrm{nm}$. The fourier transform infrared (FTIR) spectra of the nanoparticles were analyzed using FTIR spectroscopy (Shimadzu) at a resolution of $4 \mathrm{~cm}^{-1}$. The size, shape, and morphology of the biosynthesized SNPs were determined using scanning electron microscopy (SEM).
Antibacterial activity of the SNPs against some selected (MDR) Salmonella spp. and their synergetic effect with some selected antibiotics

The antibacterial activity of the biosynthesized SNPs and the synergistic effect of SNPs along with some selected antibiotics (ciprofloxacin, Zinacef, amoxicillin, Rocephin, streptomycin, Ampiclox, and gentamycin) were tested using agar well diffusion ${ }^{30}$ against the selected MDR Salmonella spp. as previously described.

Determination of minimum inhibitory concentration (MIC) of the biosynthesized SNPS

MIC was determined using different concentrations (100\%, $50 \%, 25 \%, 12.5 \%, 6.25 \%$, and $3.125 \%$ ) of the SNPs against the isolates. ${ }^{30}$ The lowest dilution of the SNPs at which ZOls were observed against the Salmonella sp. is regarded as the MIC for the SNPs. Ciprofloxacin was used as a positive control.

\section{Effect of physiochemical parameters on SNP biosynthesis}

The effects of temperature $\left(25^{\circ} \mathrm{C}, 35^{\circ} \mathrm{C}\right.$, and $\left.40{ }^{\circ} \mathrm{C}\right), \mathrm{pH}(4,7$, and 9), and different concentrations of $\mathrm{AgNO}_{3}(2-10 \mathrm{mM})$ on the biosynthesized SNPs were evaluated.

\section{Statistical analysis}

The results were subjected to One-Way ANOVA using Minitab student Release 12 (Minitab Inc., State College, PA, USA). Statistically significant means were separated using Duncan's multiple range test and Fisher pairwise comparisons. A significance level of $p \leq 0.05$ was used for the rejection of the null hypothesis.

\section{RESULTS AND DISCUSSION}

The antimicrobial activity of the bioactive metabolites of the Bacillus spp. against some MDR Salmonella spp. is shown in Table 1. The antimicrobial activity of Bacillus subtilis BAC1, B. licheniformis BAC7, and Bacillus subtilis BAC20 bioactive metabolites against the 10 MDR Salmonella strains was 3.0-17.0 mm, 4-14 mm, and 14-2.0 mm. MDR Staphylococcus aureus 9 (MDRSA9) and MDRSA20 had the highest susceptibility.

The ability of the Bacillus spp. metabolites to inhibit the test pathogens may be as a result of the production of some bioactive metabolites. Several antimicrobial activities of Bacillus spp. against pathogens have been reported. Antagonistic activity of Bacillus subtilis and Bacillus cereus against Staphylococcus spp. has been reported by Perez et al. ${ }^{13}$ and Riley and Wertz. ${ }^{32}$

Biosynthesis of SNPs using Bacilli spp. broth

The 3 bioactive metabolites were able to bioreduce the $\mathrm{AgNO}_{3}$ to produce SNPs by the evident change in color from a whitish reaction mixture to darkish brown, which indicates the formation of SNPS.

The biosynthesis of SNPs was done using the bioactive metabolites of Bacillus spp. with the highest antagonistic potential from the previous screening. This is in accordance with the work by Kalishwaralal et al. ${ }^{33}$ who biosynthesized SNPs from culture supernatant of Bacillus licheniformis. The culture supernatant was able to bioreduce $\mathrm{Ag}^{+}$to $\mathrm{Ag}^{\circ}$. Kanmani 
and $\mathrm{Lim}^{34}$ reported the bioreduction of $\mathrm{Ag}^{+}$to $\mathrm{Ag}^{\circ}$ using exopolysaccharides.

Changes in color from white to brown indicate SNP biosynthesis. A visible color change from whitish yellow to brown was also reported by El-Batal et al. ${ }^{35}$ Changes in color may be attributed to the surface plasmon resonance (SPR). ${ }^{34}$

\section{Spectrophotometric analysis of the biosynthesized SNPS}

The biosynthesized SNPs were characterized by UV-Vis spectroscopy. UV-absorption measurements in the range of 200-1000 nm were observed (Figures 1A-1C).

The UV spectra of the biosynthesized SNPs using BAC1 metabolites incubated for 24, 48, and $72 \mathrm{~h}$ had the highest SPR peak at $600 \mathrm{~nm}$ (Figure 1c). SNPs from BAC7 metabolites had the highest SPR peak at $800 \mathrm{~nm}, 600 \mathrm{~nm}$, and $400 \mathrm{~nm}$ (Figure 1b). SNPs from BAC20 metabolites had the highest SPR peak at $600 \mathrm{~nm}, 600 \mathrm{~nm}$, and $800 \mathrm{~nm}$ after 24, 48, and $72 \mathrm{~h}$ of incubation (Figure $1 \mathrm{C}$ ), which corresponds to plasmon excitation of the SNPs. All the peaks obtained were in the range of $400-800 \mathrm{~nm}$. There was variation in the SPR peaks of the SNPs incubated for different time intervals.

Primary confirmation of SNP biosynthesis was carried out by UV-Vis spectroscopy in the range of $200-1000 \mathrm{~nm}$. A strong SPR peak was observed at $600 \mathrm{~nm}$ for the SNPs biosynthesized by the Bacillus subtilis BAC1 and BAC20 after $24 \mathrm{~h}$ of incubation,

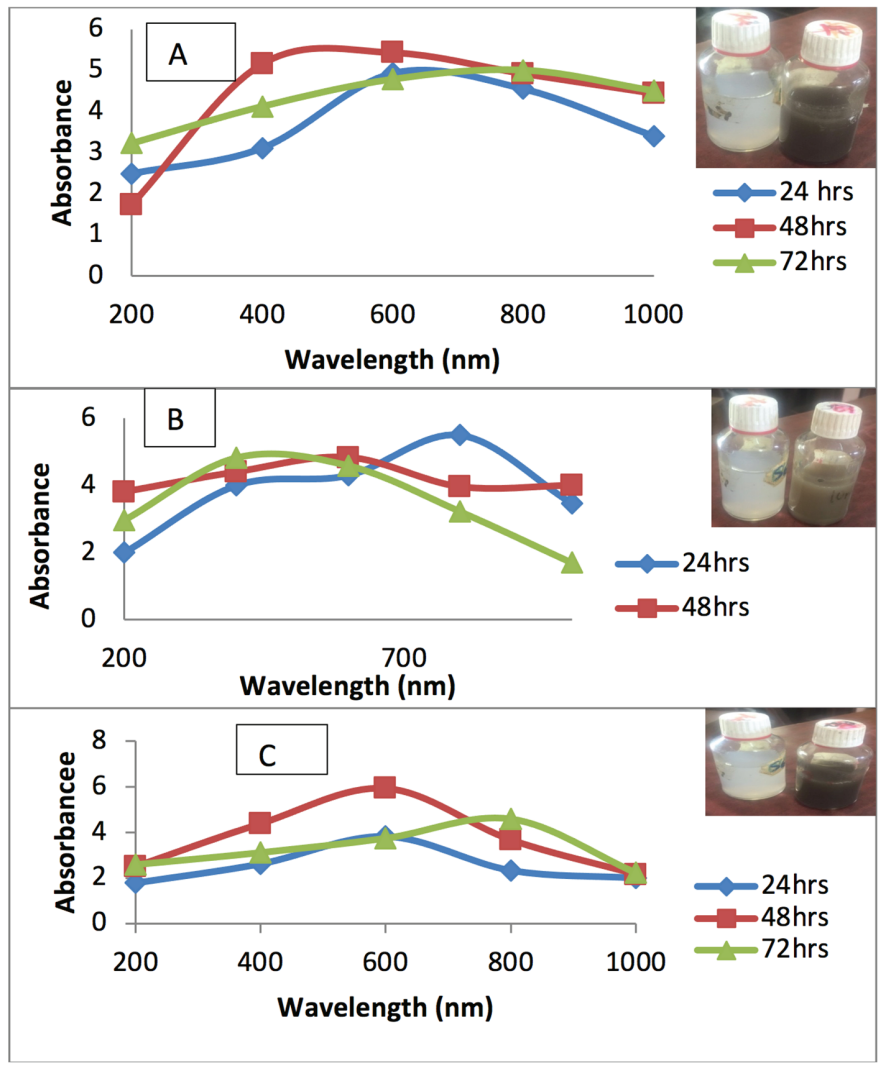

Figure 1A-C. UV-Visible spectra of the SNPs biosynthesized using metabolites of Bacillus spp. A) BAC1-SNPs, B) BAC7-SNPs, and C) BAC20SNPs at different incubation times

UV: Ultraviolet, SNPs: Silver nanoparticles, BAC1: Bacillus subtilis, BAC7: B. licheniformis, BAC20: Bacillus subtilis indicating the formation of SNPs that varied in shape and size. Kanmani and Lim $^{34}$ reported a strong SPR peak at 400-550 nm with a broad band. El-Batal et al. ${ }^{35}$ reported an SPR band at $431 \mathrm{~nm}$ of SNPs synthesized with Bacillus stearothermophilus, indicating the presence of spherical or roughly spherical SNPs. Valencia et al. ${ }^{36}$ reported that solutions containing SNPs changed to yellow from an initial whitish color and presented SPR peaks between 411 and $414 \mathrm{~nm}$.

\section{Scanning electron microscopy}

The biosynthesized SNPs were characterized by SEM. Figures $2 a-2 c$ show the micrographs of the SNPs. The SEM images show that SNPs from BAC1, BAC7, and BAC20 were of varying shape and size. BAC1-SNPs were aggregated, BAC7-SNPs were aggregated rods, and BAC20-SNPs were crystalline in shape (Figures 2A-2C). Their sizes were $15 \mu \mathrm{m}, 13 \mu \mathrm{m}$, and 10 $\mu \mathrm{m}$, respectively.

SEM is used for morphological characterization at the nanometer to micrometer scale and can provide morphological information on the submicron scale and elemental information at the micron scale as reported by Schaffer et al. ${ }^{37}$

SEM studies revealed that the biologically synthesized SNPs were different in size and shape and they showed that they were aggregated, rod shaped, and crystalline. The aggregation observed may have been due to the drying process. This observation agrees with the work by Sadowski et al. ${ }^{38}$ who observed aggregated SNPs biosynthesized using Penicillium strains isolated from soil. They concluded that the drying can affect the shape and size of SNPs.

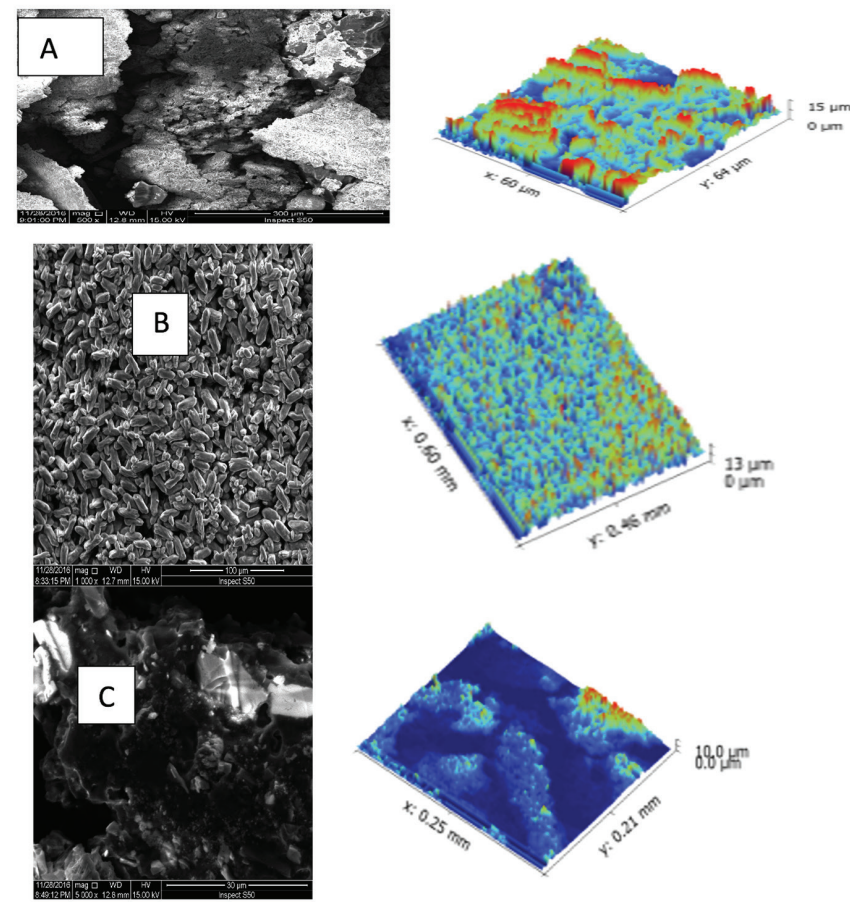

Figure 2A-C. SEM micrograph of SNPs biosynthesized using metabolites of Bacillus spp. (A), BAC1-SNPs, B) BAC7-SNPs, and C) BAC20-SNPs SEM: Scanning electron microscope, SNPs: Silver nanoparticles, BAC1: Bacillus subtilis, BAC7: B. licheniformis, BAC20: Bacillus subtilis 
The rod shape observed in BAC7-SNPs is in accordance with the work by Gardea-Torresday et al. ${ }^{39}$ who reported a rod shape from the SEM characterization of biosynthesis of gold nanoparticles from Triticum aestivum leaves.

The crystalline SNPs observed in the present work agree with the report by Vithiya et al. ${ }^{40}$ who stated that the extracellular biosynthesized SNPs from Bacillus spp. were monodispersed.

\section{FTIR spectra of the SNPS}

FTIR analysis of the SNPs was carried out to identify interactions between silver salts and protein molecules, which could account for the reduction of silver ions and stabilization of the SNPs formed.

The BAC1-SNPs characterized using FTIR show 7 bands with transmission peaks at 3448.00, 2937.14, 1638.92, 1552.59, 1404.40, 1103.65, and $607.24 \mathrm{~cm}^{-1}$ (Figure 3A). The bands corresponded to $\mathrm{O}-\mathrm{H}$ stretch of alcohol, $\mathrm{C}-\mathrm{H}$ symmetrical stretch, presence of amide, $\mathrm{NH}$ bend, $\mathrm{C}=\mathrm{O}$ stretch, $\mathrm{C}-\mathrm{O}$ stretch of alcohol, and acetylenic $\mathrm{CH}$ of alkynes, respectively. The functional groups generally observed indicated the presence of amino acids, alcohol, aldehydes, and carboxylic acid in the sample and this may have been responsible for the reduction of $\mathrm{AgNO}_{3}$ to SNPs.

The FTIR analysis of BAC7-SNPs shows 9 bands and the peaks' spectrum ranged from $3423.00 \mathrm{~cm}^{-1}$ to $352.84 \mathrm{~cm}^{-1}$ (Figure 3B). The peaks were attributed to $\mathrm{O}-\mathrm{H}$ stretch vibration of alcohol, symmetrical $\mathrm{C}-\mathrm{H}, \mathrm{C}=\mathrm{O}$ stretch of carboxylates and $\mathrm{NH}$ stretch of secondary amides, presence of $\mathrm{O}-\mathrm{H}$ bends of esters, phenol and tertiary alcohol or $\mathrm{C}-\mathrm{C}$ bend of aldehyde, $\mathrm{C}-\mathrm{O}$ stretching vibration of carboxylic esters, $\mathrm{C}-\mathrm{O}$ stretching vibration of secondary alcohol, and presence of acetylenic $\mathrm{CH}$ of alkynes and aromatic benzene ring. From the FTIR spectrum, it was observed that the SNPs were surrounded by carboxylic acid, aldehyde, esters, protein, and amino acids, which may have been responsible for the biosynthesis and stability of the SNPs (Figure 3B).

The FTIR analysis of BAC20-SNPs revealed 12 absorption peaks that ranged between $3760.00 \mathrm{~cm}^{-1}$ and $361.39 \mathrm{~cm}^{-1}$. The peak indicated the presence of an $\mathrm{O}-\mathrm{H}$ stretch free, strong alcohol, $\mathrm{O}-\mathrm{H}$ stretch vibration of alcohol, $\mathrm{C}-\mathrm{H}$ symmetrical stretching, carbonyl stretching of transition metals, $\mathrm{NH}$ bend of amide, $\mathrm{NH}$ stretch of secondary amides, C-O stretch of esters, carboxylic acids, acetylenic $\mathrm{CH}$ of alkynes, and weak aromatic benzene. The functional groups that corresponded to the FTIR spectrum generally indicated the presence of amino acids, alcohol, aldehydes, and carboxylic acid, which may have been responsible for the reduction of $\mathrm{AgNO}_{3}$ to SNPs (Figure $3 c$ ). The presence of the intense peak in $\mathrm{C}=\mathrm{O}$ stretching mode indicates the presence of carboxylic groups in the material bound to SNPs.

The FTIR measurements were obtained to identify possible interactions between silver salts and protein molecules. FTIR is very useful for SNP characterization as reported by Kanmani and Lim. ${ }^{34}$ El-Batal et al. ${ }^{35}$ reported that the release of extracellular protein molecules from bacteria could possibly perform the function of formation and stabilization of SNPs in aqueous medium. Balashanmugam et $a{ }^{30}$ also suggested that from FTIR spectrum analysis SNPs were surrounded by proteins and amino acids, which may be responsible for the stability of the SNPS.

The functional groups such as carboxylic acid, amino acid, alcohol, esters, and aldehydes present in the SNPs biosynthesized using the Bacillus metabolites were responsible for reduction, capping, and stabilization of the nanoparticles. ElBatal et al..$^{35}$ reported functional groups as the reducing agents responsible for SNP formation and stabilization in their work.

Antibacterial activity of the biosynthesized SNPs from the Bacillus strains against MDR Salmonella spp.

The antibacterial activity of the biosynthesized SNPs from the Bacillus spp. against the selected MDR Salmonella spp. is shown in Figure 4.
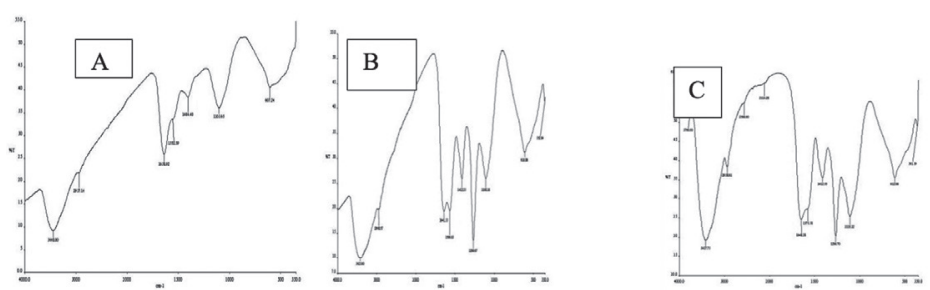

Figure 3A-C. FTIR spectra of the SNPs from Bacillus spp. A) BAC1-SNPs, B) BAC7-SNPs, and C) BAC20-SNPs

FTIR: Fourier transform infrared, SNPs: Silver nanoparticles, BAC1: Bacillus subtilis, BAC7: B. licheniformis, BAC20: Bacillus subtilis

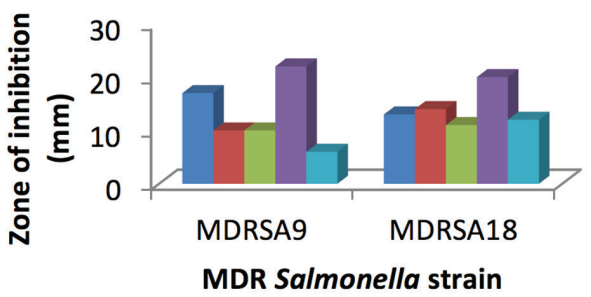

BAC 1-SNPS

BAC 7-SNPS

BAC 20-SNPS

- Ciprofloxacin

agNO3

Figure 4. Antibacterial activity of the synthesized SNPs against the selected (MDR) Salmonella spp.

MDR: Multidrug resistant, SNPs: Silver nanoparticles, $\mathrm{AgNO}_{3}$ : Silver nitrate, MDRSA: Multidrug resistant Staphylococcus aureus, BAC1: Bacillus subtilis, BAC7: B. licheniformis, BAC20: Bacillus subtilis

The antibacterial activity of BAC1-SNPs, BAC7-SNPs, and BAC20-SNPs against MDRSA9 ranged from 6.0 to $22 \mathrm{~nm}$. MDRSA9 had the highest susceptibility to BAC1-SNPs. BAC7SNPs and BAC20-SNPs exhibited higher activity against the MDRSA9 compared to $\mathrm{AgNO}_{3}$. Ciprofloxacin exhibited higher activity against MDRSA9 compared to the SNPs.

The antibacterial activity of BAC1-SNPs, BAC7-SNPs, and BAC20-SNPs against MDRSA18 ranged from 11 to $20 \mathrm{~nm}$. All the biosynthesized SNPs had antagonistic activity against MDRSA18. BAC7-SNPs exhibited higher antagonistic activity against MDRSA18 than BAC1-SNPs and BAC20-SNPs. 
BAC1-SNPs had the highest antagonistic potential against MDRSA9 while BAC7-SNPs and BAC20-SNPs had the highest antagonistic potential against MDRSA18. Ciprofloxacin exhibited higher activity against MDRS18 compared to the SNPs.

Guzman et al. ${ }^{41}$ reported the possibility of SNPs acting similarly to the antimicrobial agents used for the treatment of bacterial infections, which show four different mechanisms of action, including interference with cell wall synthesis, inhibition of protein synthesis, interference with nucleic acid synthesis, and inhibition of metabolic pathway. Sharma et al. ${ }^{42}$ also noted that SNPs not only interact with the surface of the membrane, but can also penetrate inside the bacteria. It is reported that the bactericidal effect of SNPs decreases as the size increases and is also affected by the shape of the particles. Dhanalakshmi and Rajendran ${ }^{43}$ reported the interaction of nanoparticles with the DNA inside a bacterium thus losing its ability to replicate, which may lead to cell death.

The antibacterial activities of the SNPs produced from Bacillus spp. metabolites against MDR Salmonella spp. are in agreement with the work by Natarajan and Selvaraj ${ }^{44}$ who reported the antibacterial activity of SNPs produced from Bacillus subtilis against pathogens like Escherichia coli, Staphylococcus epidermidis, Staphylococcus coagulase positive, Serratia spp., and Salmonella typhi. They also stated that the SNPs showed the most activity against Salmonella typhi. This is not in accordance with Kanmani and $\operatorname{Lim}^{34}$ who reported that Gramnegative bacteria were more susceptible to SNPs than Grampositive bacteria.

\section{MIC of the SNPs against the MDR Salmnella spp.}

The MIC of the SNPs against the MDR Salmonella spp. is shown in Table 2. BAC1- SNPs had an MIC of $3.25 \%$ on SA9 and $6.25 \%$ on SA18. BAC7-SNPs had an MIC of $3.25 \%$ on SA9 and of $6.25 \%$ on SA18. The BAC20-SNPs had an MIC of $6.25 \%$ on SA9 and $3.25 \%$ on SA18. Salmonella spp. SA9 was resistant to BAC20-SNPs at a concentration of $3.25 \%$, while Salmonella sp. SA18 was resistant to BAC1-SNPs and BAC7-SNPs at a $3.25 \%$ concentration.

The MIC was defined as the lowest concentration of the SNPS that can have an antimicrobial effect on the test organisms; 10 $\mathrm{mM}$ was used to prepare the different concentrations of the SNPs for the MIC evaluation and different MICs were recorded for the two (MDR) Salmonella spp. Balashanmugam et al..$^{30}$ also reported the MIC of their SNPs after testing on some pathogens, with Escherichia coli and Bacillus subtilis having the highest values.

\section{Effect of temperature on SNP biosynthesis}

The effect of temperature $\left(25-40{ }^{\circ} \mathrm{C}\right), \mathrm{pH}$ (4-9), and different concentrations of $\mathrm{AgNO}_{3}(2-10 \mathrm{mM})$ on the biosynthesis of SNPs was evaluated and the SNPs were characterized.

The UV-Vis spectra of BAC1-SNPs had a sharp SPR peak at 400 and 800 at $25^{\circ} \mathrm{C}$ and $35^{\circ} \mathrm{C}$. At $40{ }^{\circ} \mathrm{C}$, a sharp SPR peak was observed at $600 \mathrm{~nm}$. SNPs synthesized at $35^{\circ} \mathrm{C}$ had the highest SPR peak (Figure 5A). For BAC7- SNPs biosynthesized at $25^{\circ} \mathrm{C}, 35^{\circ} \mathrm{C}$, and $40{ }^{\circ} \mathrm{C}$, the sharp SPR peak was observed at $400 \mathrm{~nm}$ and $800 \mathrm{~nm}$ (Figure 5B). For BAC20-SNP at $25^{\circ} \mathrm{C}$ and $40{ }^{\circ} \mathrm{C}$, the UV-Vis spectra showed a sharp SPR peak at $400 \mathrm{~nm}$ and $800 \mathrm{~nm}$, while at $35^{\circ} \mathrm{C}$, the sharp SPR peak was observed at $600 \mathrm{~nm}$ (Figure $5 \mathrm{C}$ ). The highest absorbance values were obtained at $35{ }^{\circ} \mathrm{C}$ followed by $40{ }^{\circ} \mathrm{C}$ for all the SNPs. The optimum temperature for the production of SNPs was $35^{\circ} \mathrm{C}$

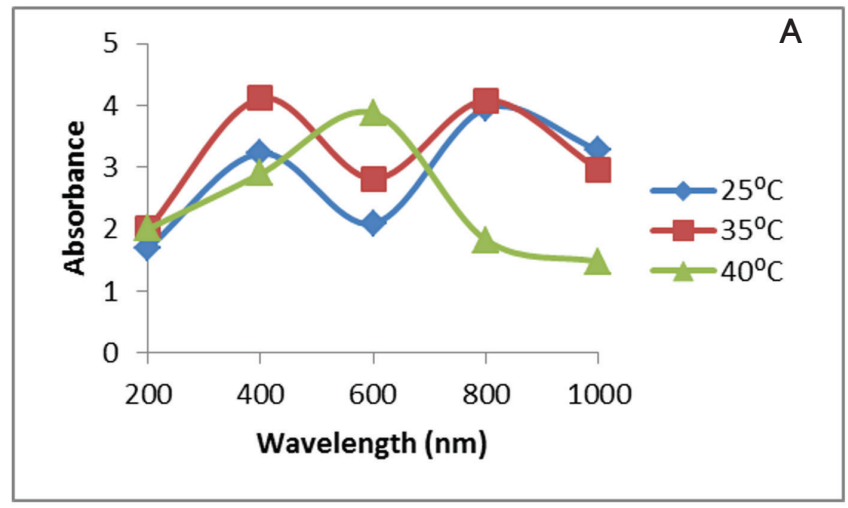

Figure 5A. UV-Visible spectra of BAC1 SNPs at different temperature UV: Ultraviolet, SNPs: Silver nanoparticles, BAC1: Bacillus subtilis

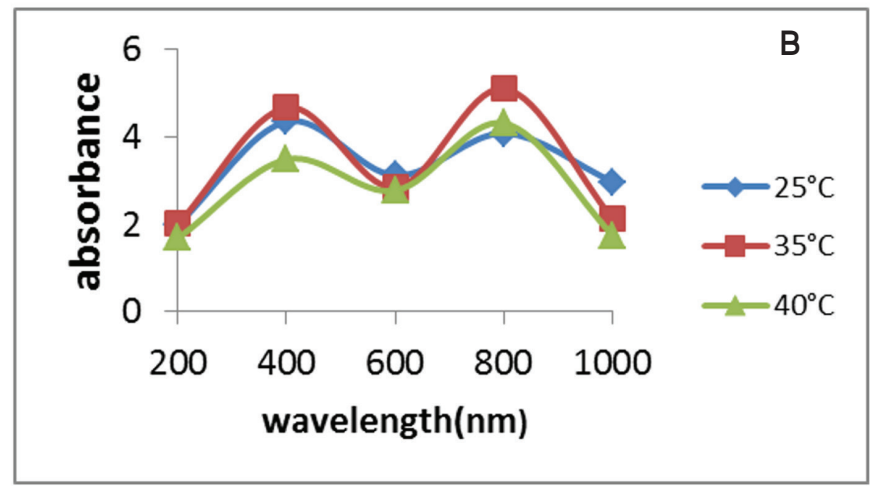

Figure 5B. UV-Visible spectra of BAC7 SNPs at different temperature UV: Ultraviolet, SNPs: Silver nanoparticles, BAC7: B. licheniformis Table 1. Antimicrobial activity $(\mathrm{mm})$ of the bioactive metabolites of Bacillus spp. against some multidrug resistant Salmonella spp.

\begin{tabular}{|c|c|c|c|c|c|c|c|c|c|c|}
\hline \multirow{2}{*}{$\begin{array}{l}\text { Bioactive Bacillus } \\
\text { spp. metabolites }\end{array}$} & \multicolumn{10}{|c|}{ MDR Salmonella strains/Zone of inhibition ( $\mathrm{mm}$ ) } \\
\hline & SA23 & SA15 & SA32 & SA20 & SA32b & SA9 & SA7 & SA18 & SA21 & SA8 \\
\hline $\mathrm{BSM}(\mathrm{BAC1})$ & $7.0 \pm 0.5^{\mathrm{e}}$ & $11.0 \pm 1.0^{b}$ & $8.0 \pm 0.5^{d}$ & $5.0 \pm 1.00^{f}$ & $4.0 \pm 1.0^{\mathrm{fg}}$ & $17.0 \pm 0.5^{\mathrm{a}}$ & $4.0 \pm 1.0^{\mathrm{fg}}$ & $10.0 \pm 1.0^{c}$ & $0.0 \pm 0.0^{h}$ & $3.0 \pm 0.5^{g}$ \\
\hline BMM (BAC20) & $2.0 \pm 0.0^{f}$ & $0.0 \pm 0.0^{g}$ & $0.0 \pm 0.0^{g}$ & $14.0 \pm 1.0^{a}$ & $12.0 \pm 0.0^{c}$ & $6.0 \pm 1.0^{e}$ & $2.0 \pm 0.0^{f}$ & $11.0 \pm 0.0^{d}$ & $6.0 \pm 0.0^{e}$ & $13.0 \pm 0.5^{b}$ \\
\hline
\end{tabular}

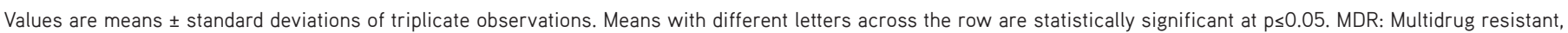

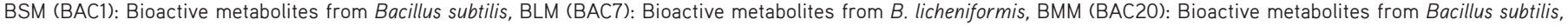
BAC20, a, b, c, d, e, f, g: Are statistically significant letters from Duncan multiple range test 
The effect of temperature on SNP synthesis was evaluated and the best temperature was $35^{\circ} \mathrm{C}$. This is not in accordance with the work by Amin et al. ${ }^{45}$ who observed that with an increase in temperature from $25{ }^{\circ} \mathrm{C}$ to $45{ }^{\circ} \mathrm{C}$ the SPR peaks became sharper and an absorption band at $406 \mathrm{~nm}$ was obtained, which suggested the formation of SNPs.

Annadurai et al. ${ }^{46}$ also reported that the synthesis of SNPs from leaf extract of Coleus aromaticus increased when the reaction temperature was increased and they concluded that a higher temperature $\left(70{ }^{\circ} \mathrm{C}\right.$ ) was best for nanoparticle synthesis. Amin et al. $^{45}$ observed that the best temperature required for the completion of the reaction was $45^{\circ} \mathrm{C}$.

\section{Effect of $\mathrm{pH}$ on SNP biosynthesis}

The UV spectra of the effect of different $\mathrm{pH}$ values $(4,7$, and 9) on SNP biosynthesis are shown in Figures 6A-6C. The UVVis spectra of BAC1-SNPs produced at different $\mathrm{pH}$ values are shown in Figure 6A. At pH 4 and 7 a sharp peak was observed at $600 \mathrm{~nm}$, while at $\mathrm{pH} 9$ a sharp SPR peak was observed at $400 \mathrm{~nm}$. The highest absorbance was observed at $\mathrm{pH}$ 7. The UV-Vis spectra of BAC7-SNPs at $\mathrm{pH} \mathrm{4,} \mathrm{pH} 7$, and $\mathrm{pH} 9$ had a broad spectrum between $400 \mathrm{~nm}$ and $800 \mathrm{~nm}$. BAC7-SNPs at $\mathrm{pH} 7$ had a sharp peak at $200 \mathrm{~nm}$ (Figure 6B). The UV-Vis spectra of BAC20-SNPs biosynthesized at different $\mathrm{pH}$ values are shown in Figure 5C. BAC20-SNPs had the highest sharp SPR peak at $600 \mathrm{~nm}$. The SNPs biosynthesized at $\mathrm{pH} 4$ and 7 had a broad band between $600 \mathrm{~nm}$ and $800 \mathrm{~nm}$.

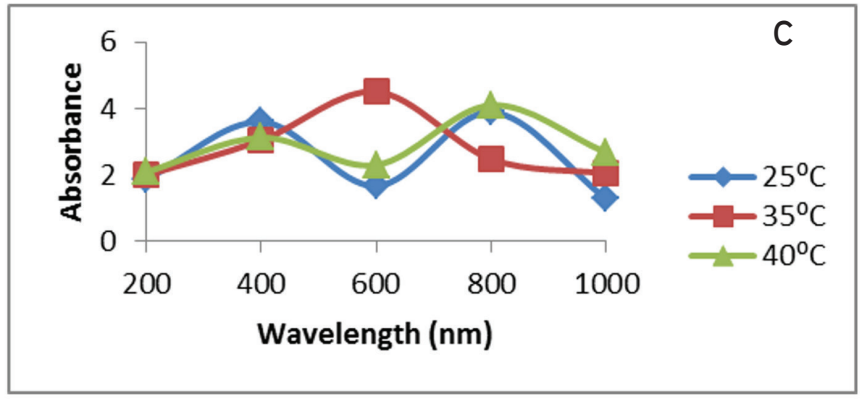

Figure 5c. UV-Visible spectra of BAC20 SNPs at different temperature UV: Ultraviolet, SNPs: Silver nanoparticles, BAC20: Bacillus subtilis
The optimum $\mathrm{pH}$ for the production of SNPs by Bacillus spp. fermentation broth was 7 . Goldie et al. ${ }^{47}$ reported that the optimum $\mathrm{pH}$ for extracellular fabrication of SNPs using Pseudomonas aeruginosa was 10 . Annadurai et al. ${ }^{47}$ reported

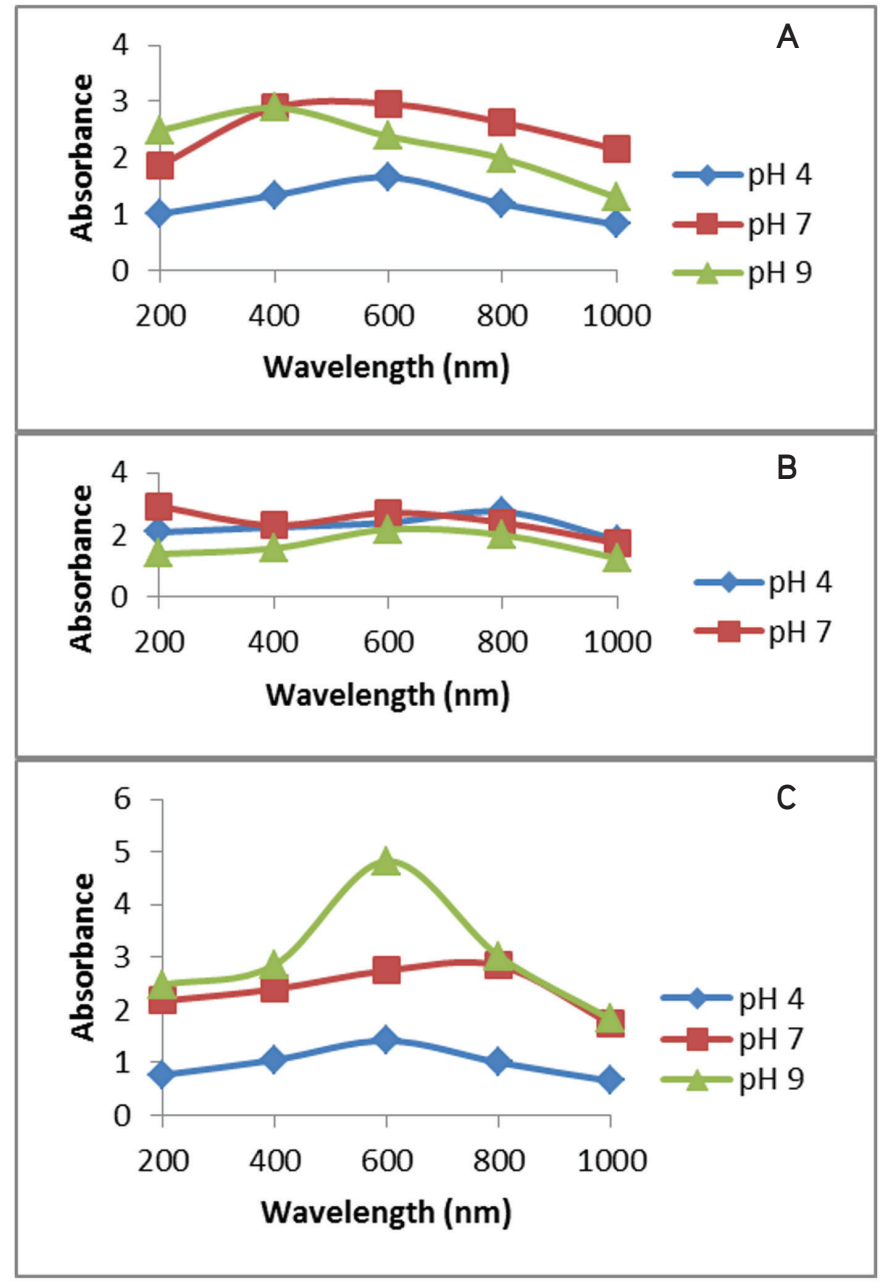

Figure 6A-C. UV-Visible spectra of SNPs biosynthesized at different $\mathrm{pH}$ by Bacillus spp. A), BAC1-SNPs, B) BAC7-SNPs and C) BAC20 SNPs

UV: Ultraviolet, SNPs: Silver nanoparticles, BAC1: Bacillus subtilis, BAC7: B. licheniformis, BAC20: Bacillus subtilis

Table 2. Determination of minimum inhibitory concentration of Bacillus spp. silver nanoparticles on the selected multidrug resistant Salmonella spp.

Zones of inhibition $(\mathrm{mm})$

\begin{tabular}{|c|c|c|c|c|c|c|}
\hline \multirow[t]{2}{*}{ MIC concentration (\%) } & \multicolumn{3}{|c|}{ MDRSA9 } & \multicolumn{3}{|c|}{ MDRSA18 } \\
\hline & BAC1-SNPs & BAC7-SNPs & BAC20-SNPs & BAC1-SNPs & BAC7-SNPs & BAC20-SNPs \\
\hline 50 & $13 \pm 0.0^{\mathrm{ab}}$ & $14.0 \pm 0.2^{\mathrm{a}}$ & $12.0 \pm 0.7^{b}$ & $10.0 \pm 0.0^{b}$ & $12.0 \pm 1.0^{a}$ & $8.0 \pm 0.5^{c}$ \\
\hline 25 & $12 \pm 0.4^{b}$ & $14.0 \pm 0.5^{\mathrm{a}}$ & $10.0 \pm 1.0^{c}$ & $12.0 \pm 0.2^{a}$ & $10.0 \pm 0.0^{b}$ & $10.0 \pm 0.3^{b}$ \\
\hline 12.5 & $9.0 \pm 1.0^{\mathrm{b}}$ & $12.0 \pm 0.6^{a}$ & $12.0 \pm 0.0^{\mathrm{a}}$ & $9.0 \pm 0.6^{\mathrm{a}}$ & $8.0 \pm 1.0^{\mathrm{b}}$ & $6.0 \pm 1.0^{c}$ \\
\hline 6.25 & $6.0 \pm 1.0^{b}$ & $8.0 \pm 0.0^{\mathrm{a}}$ & $5.0 \pm 0.3^{c}$ & $5.0 \pm 1.0^{\mathrm{a}}$ & $4.0 \pm 0.1^{b}$ & $4.0 \pm 0.15^{b}$ \\
\hline Ciprofloxacin & $12.0 \pm 0.5^{b}$ & $14.0 \pm 0.0^{a}$ & $4.0 \pm 0.2^{c}$ & $10.0 \pm 0.8^{a}$ & $10.0 \pm 0.0^{a}$ & $1.0 \pm 0.5^{b}$ \\
\hline
\end{tabular}

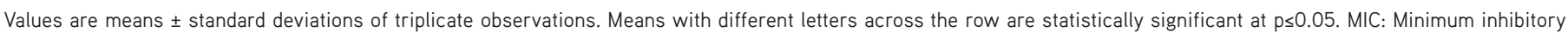

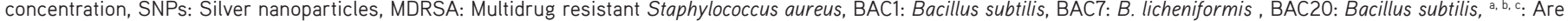
statistically significant letters from Duncan multiple range test 
that alkaline $\mathrm{pH}$ was more suitable for SNP synthesis by Coleus aromaticus. Amin et al. ${ }^{45}$ reported more SNPs biosynthesized under basic conditions, while the formation of SNPs was repressed by acidic conditions and at lower $\mathrm{pH}(\mathrm{pH}$ ) larger nanoparticles were formed, whereas at higher $\mathrm{pH}(\mathrm{pH} 9)$ smaller and highly dispersed nanoparticles were formed.

Antimicrobial potential of $\mathrm{AgNO}_{3}$ and SNPs biosynthesized at different $p H$ values against MDR-Salmonella spp.

The antimicrobial activity of the SNPs biosynthesized at different $\mathrm{pH}$ values against MDR-SA9 is shown in Table 3a. All the $\mathrm{AgNO}_{3}$ and the SNPs had antimicrobial activity against MDR-SA9.

The antibacterial activity of BAC1-SNPs, BAC7-SNPs, and BAC20-SNPs at $\mathrm{pH} 4, \mathrm{pH} \mathrm{7}$, and $\mathrm{pH} 9$ against MDR-SA9 was 8-16 mm, 4-14 mm, and 4-14 mm, respectively. BAC1-SNPs produced at $\mathrm{pH} 9$ and BAC7-SNPs and BAC20-SNPs produced at $\mathrm{pH} 7$ exhibited the highest antagonistic activity against MDRSA9.

The antimicrobial activity of SNPs biosynthesized at different $\mathrm{pH}$ values by Bacillus spp. against MDR-SA18 is shown in Table 3b. The SNPs had antimicrobial activity against MDR-SA18 at different $\mathrm{pH}$ values. The antimicrobial activity of BAC1-SNPs, BAC7-SNPs, and BAC20-SNPs against MDR-SA18 was 4.0$9.0 \mathrm{~mm}, 4.0-9.0 \mathrm{~mm}$, and 3.0-10 mm, respectively. The highest activity was recorded at $\mathrm{pH}$ 7. There was no ZOI at $\mathrm{pH} 9$ by BAC1SNPs or BAC7-SNPs against MDR-SA18 after $24 \mathrm{~h}$ of incubation.

Effect of different concentrations of $\mathrm{AgNO}_{3}$ on SNP biosynthesis The effect of different concentrations (2-10 mM) of $\mathrm{AgNO}_{3}$ solutions on the biosynthesis of SNPs was evaluated and was monitored by UV-Visible spectrophotometer. Figure 7A shows the spectra of BAC1-SNPs produced at different concentrations of silver nitrate. The SPR peak was observed at $400 \mathrm{~nm}$ for Bacillus sp. BAC1 SNPs produced with $8 \mathrm{mM}$. The SNPs produced with $2 \mathrm{mM}$ and $4 \mathrm{mM}$ of $\mathrm{AgNO}_{3}$ had a broad band between $400 \mathrm{~nm}$ and $800 \mathrm{~nm}$. The SNPs produced with $10 \mathrm{mM}$ $\mathrm{AgNO}_{3}$ had a strong SPR peak at $600 \mathrm{~nm}$.

The spectra obtained for BAC7 SNPs produced with different concentrations of $\mathrm{AgNO}_{3}$ are shown in Figure 7B. A broad band spectrum between $400 \mathrm{~nm}$ and $600 \mathrm{~nm}$ was observed for the SNPs synthesized with $2 \mathrm{mM}, 6 \mathrm{mM}$, and $8 \mathrm{mM}$ concentrations of $\mathrm{AgNO}_{3}$. The SNPs produced with the $10 \mathrm{mM} \mathrm{AgNO}_{3}$ has a strong peak at $600 \mathrm{~nm}$. The $10 \mathrm{mM} \mathrm{AgNO}_{3}$ concentration had the highest OD.

The effect of concentration on the biosynthesis of Bacillus sp. BAC20 SNPs is presented in Figure 7c. The SNPs produced with $2 \mathrm{mM}$ to $10 \mathrm{mM} \mathrm{AgNO}_{3}$ concentration all had a broad band spectrum between $400 \mathrm{~nm}$ and $800 \mathrm{~nm}$. A SPR peak of $600 \mathrm{~nm}$ was observed for $2 \mathrm{mM}, 4 \mathrm{mM}$, and $6 \mathrm{mM}$. The highest OD was shown by the SNPs produced with $10 \mathrm{mM}$ at $500 \mathrm{~nm}$.

Antimicrobial potential of SNPs biosynthesized using different concentrations of $\mathrm{AgNO}_{3}$

The antimicrobial activity of the SNPs biosynthesized by Bacillus spp. using different concentrations of $\mathrm{AgNO}_{3}$ is shown in Tables $4 a$ and $4 b$.

All the SNPs produced by Bacillus spp. using different concentrations of $\mathrm{AgNO}_{3}$ had antagonistic activity against the isolates. The antimicrobial activity of BAC1-SNPs, BAC7-SNPs, and BAC20-SNPs against MDR-SA9 was 6-24 mm, 2-25 mm, and $2-20 \mathrm{~mm}$ at 24,48 , and $72 \mathrm{~h}$ of incubation, respectively. The highest antagonistic activity $(15 \mathrm{~mm})$ against SA9 was shown by $10 \mathrm{mM} \mathrm{AgNO}_{3}$.

\begin{tabular}{l}
$\begin{array}{l}\text { Table 3a. The antimicrobial potential of silver nitrate and silver nanoparticles biosynthesized at different pH values against multidrug } \\
\text { resistant-SA9 }\end{array}$ \\
\cline { 2 - 7 } Samples \\
\cline { 2 - 7 }
\end{tabular}

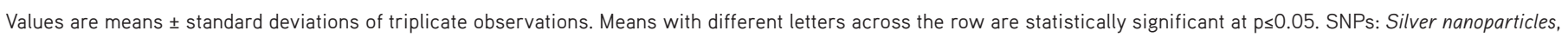
SA: Staphylococcus aureus, BAC1: Bacillus subtilis, BAC7: B. licheniformis, BAC20: Bacillus subtilis, a, b, c, d, e: Are statistically significant letters from Duncan multiple range test

Table 3b. The antimicrobial potential of silver nitrate and silver nanoparticles biosynthesized at different pH values against multidrug resistant-SA18

\begin{tabular}{llllclc} 
& \multicolumn{5}{c}{ Antimicrobial activity (mm) } \\
\cline { 2 - 6 } Samples & \multicolumn{3}{c}{ BAC1-SNPs } & \multicolumn{2}{c}{ BAC7-SNPs } & BAC20-SNPs \\
\cline { 2 - 6 } & $24 \mathrm{~h}$ & $48 \mathrm{~h}$ & $24 \mathrm{~h}$ & $48 \mathrm{~h}$ & $24 \mathrm{~h}$ & $48 \mathrm{~h}$ \\
\hline SNPs pH 4 & $4.0 \pm 0.0^{\mathrm{c}}$ & $6.0 \pm 0.5^{\mathrm{b}}$ & $7.0 \pm 0.2^{\mathrm{a}}$ & $4.0 \pm 0 .^{\mathrm{c}}$ & $2.0 \pm 0.2^{\mathrm{d}}$ & $6.0 \pm 0.2^{\mathrm{b}}$ \\
\hline SNPs pH 7 & $9.0 \pm 0.4^{\mathrm{b}}$ & $8.0 \pm 0.00^{\mathrm{c}}$ & $6.0 \pm 0.0^{\mathrm{d}}$ & $9.0 \pm 0.2^{\mathrm{b}}$ & $6.0 \pm 0.50^{\mathrm{d}}$ & $10.0 \pm 0.4^{\mathrm{a}}$ \\
\hline SNPs pH 9 & $0.0 \pm 0.0^{\mathrm{d}}$ & $3.0 \pm 0.2^{\mathrm{c}}$ & $0.0 \pm 0.0^{\mathrm{d}}$ & $4.0 \pm 0.0^{\mathrm{b}}$ & $5.0 \pm 0.2^{\mathrm{a}}$ & $3.0 \pm 0.27^{\mathrm{c}}$ \\
\hline
\end{tabular}

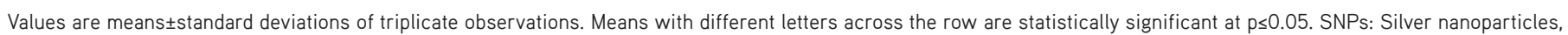
SA: Staphylococcus aureus BAC1: Bacillus subtilis, BAC7: B. licheniformis, BAC20: Bacillus subtilis, a, b, c, d: Are statistically significant letters from Duncan multiple range test 


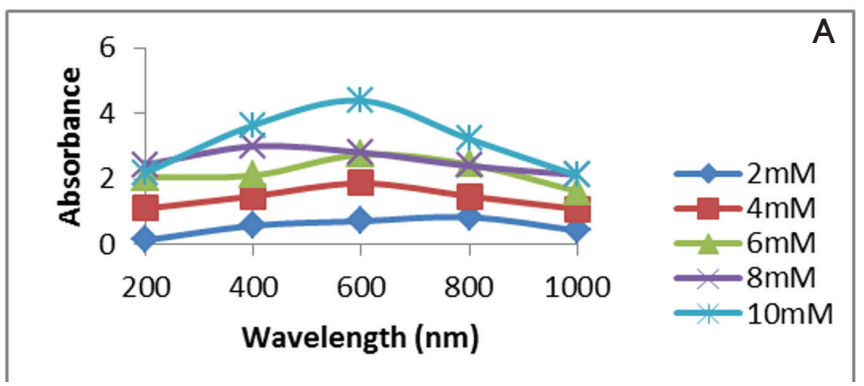

Figure 7A. UV-Visible spectra of BAC1 SNPs at different concentrations of $\mathrm{AgNO}_{3}$

UV: Ultraviolet, SNPs: Silver nanoparticles, $\mathrm{AgNO}_{3}$ : Silver nitrate, $\mathrm{BAC1}$ : Bacillus subtilis

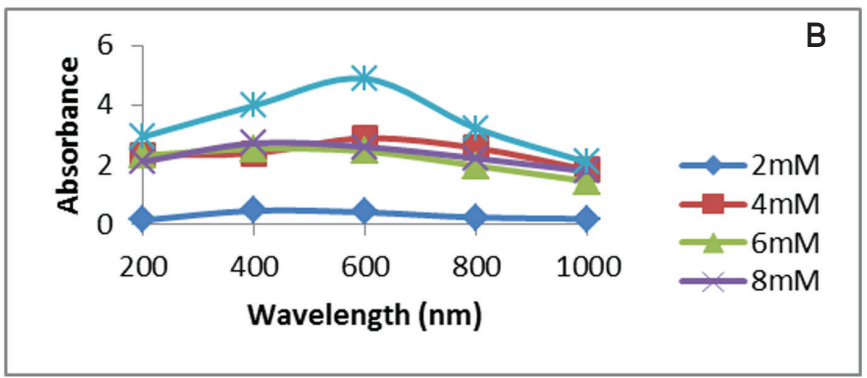

Figure 7B. UV-Visible spectra of BAC7 SNPs at different concentrations of $\mathrm{AgNO}_{3}$

UV: Ultraviolet, SNPs: Silver nanoparticles, $\mathrm{AgNO}_{3}$ : Silver nitrate, BAC1: Bacillus subtilis

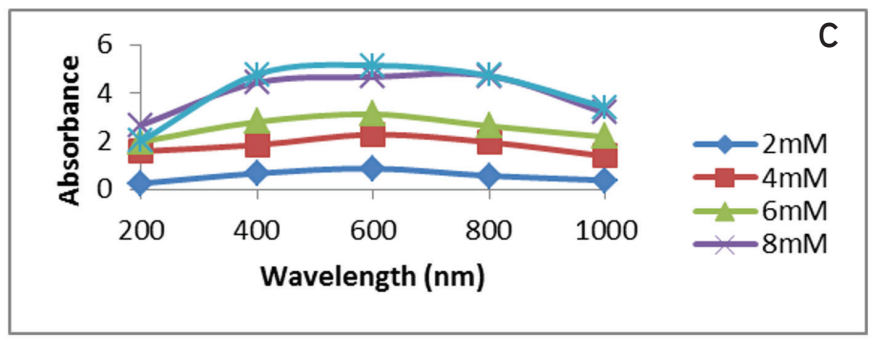

Figure 7C. UV-Visible spectra of BAC20 SNPs at different concentrations of $\mathrm{AgNO}_{3}$

UV: Ultraviolet, SNPs: Silver nanoparticles, $\mathrm{AgNO}_{3}$ : Silver nitrate, BAC20: Bacillus subtilis

Table 4a. Antimicrobial potential of silver nanoparticles biosynthesized using different concentrations of silver nitrate against multidrug

resistant-SA9 at different incubation times

Zone of inhibition $(\mathrm{mm}) /$ Incubation time $(\mathrm{h})$ against MDRSA9

\begin{tabular}{|c|c|c|c|c|c|c|c|c|c|}
\hline \multirow{2}{*}{$\begin{array}{l}\text { Concentrations of } \\
\mathrm{AgNO}_{3}\end{array}$} & \multicolumn{3}{|c|}{ BAC1-SNPs } & \multicolumn{3}{|l|}{ BAC7-SNPs } & \multicolumn{3}{|c|}{ BAC20-SNPs } \\
\hline & $24 \mathrm{~h}$ & $48 \mathrm{~h}$ & $72 \mathrm{~h}$ & $24 \mathrm{~h}$ & $48 \mathrm{~h}$ & $72 \mathrm{~h}$ & $24 \mathrm{~h}$ & $48 \mathrm{~h}$ & $72 \mathrm{~h}$ \\
\hline $2 \mathrm{mM}$ & $6.0 \pm 0.5^{e}$ & $8.0 \pm 0.0^{d}$ & $8.0 \pm 0.1^{d}$ & $4.0 \pm 0.2^{f}$ & $8.0 \pm 0.0^{d}$ & $14.0 \pm 0.0^{a}$ & $12.0 \pm 0.3^{b}$ & $6.0 \pm 0.0^{e}$ & $10.0 \pm 1.0^{c}$ \\
\hline $4 \mathrm{mM}$ & $8.0 \pm 0.0^{f}$ & $20.0 \pm 1.0^{\mathrm{a}}$ & $12.0 \pm 0.0^{d}$ & $14.0 \pm 0.45^{c}$ & $10.0 \pm 1.0^{e}$ & $12.0 \pm 1.0^{d}$ & $18.0 \pm 0.0^{\mathrm{b}}$ & $10.0 \pm 0.0^{e}$ & $8.0 \pm 0.0^{f}$ \\
\hline $6 \mathrm{mM}$ & $12 \pm 0.53^{d}$ & $17.0 \pm 0.3^{b}$ & $16.0 \pm 1.0^{c}$ & $2.0 \pm 0.0^{\mathrm{g}}$ & $10.0 \pm 0.5^{e}$ & $16.0 \pm 0.5^{c}$ & $4.0 \pm 0.10^{f}$ & $10.0 \pm 0.0^{e}$ & $18.0 \pm 0.5^{a}$ \\
\hline $8 \mathrm{mM}$ & $6.0 \pm 0.6^{f}$ & $16.0 \pm 0.0^{c}$ & $18.0 \pm 0.53^{b}$ & $6.0 \pm 0.2^{f}$ & $12.0 \pm 0.2^{e}$ & $14.0 \pm 0.3^{d}$ & $2.0 \pm 0.0^{\mathrm{g}}$ & $20.0 \pm 1.0^{a}$ & $12.0 \pm 1.0^{e}$ \\
\hline $10 \mathrm{mM}$ & $10.0 \pm 0.0^{\mathrm{g}}$ & $20.0 \pm 1.0^{d}$ & $24.0 \pm 0.25^{b}$ & $6.0 \pm 0.0^{h}$ & $22.0 \pm 1.0^{c}$ & $25.0 \pm 0.0^{\mathrm{a}}$ & $17.0 \pm 0.6^{\mathrm{e}}$ & $15.0 \pm 0.6^{f}$ & $20.0 \pm 1.0^{d}$ \\
\hline
\end{tabular}

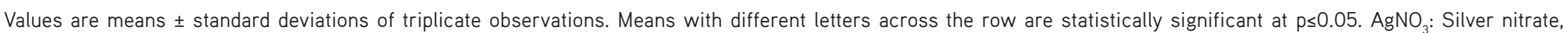

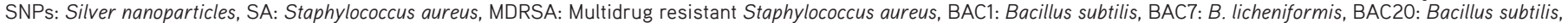
$\mathrm{a}, \mathrm{b}, \mathrm{c}, \mathrm{d}, \mathrm{e}, \mathrm{f}, \mathrm{g}, \mathrm{h}$ : Are statistically significant letters from Duncan multiple range test
The antimicrobial activity of BAC1-SNPs, BAC7-SNPs, and BAC20-SNPs against MDR-SA18 was 2.0-15 mm, 2.0-17 mm, and $2.0-21 \mathrm{~mm}$, respectively. The SNPs from the Bacillus spp. had the highest activity against MDR-SA18 at $10 \mathrm{mM}$ concentration of $\mathrm{AgNO}_{3}$.

Synergistic effect of the biosynthesized SNPs and some antibiotics against MDR Salmonella spp.

The synergetic effect of the biosynthesized SNPs and some antibiotics against MDR Salmonella sp. SA9 and MDR Salmonella sp. SA18 is shown in Figures 8A and 8B.

The MDR-SA9 showed susceptibility to antibiotics with antagonistic potential ranging between 3.0 and $20 \mathrm{~mm}$. Colistin had the lowest antagonistic activity while chlortetracycline had the highest activity.

The synergetic effect of the biosynthesized SNPs and some antibiotics against MDR-SA9 is shown in Figure 8a. The antagonistic potential of BAC1 SNPs + the antibiotics ranged from 10 to $33 \mathrm{~mm}$. BAC1 SNPs + erythromycin had the highest antagonistic activity against MDR-SA9, while BAC1 SNPs + oxytetracycline had the lowest activity.

The antagonistic potential of BAC7-SNPs + antibiotics against MDR-SA9 ranged from 6.0 to $30 \mathrm{~mm}$. BAC7-SNPs + gentamicin had the highest activity, while BAC7 SNPs + colistin had the lowest antagonistic activity. The antagonistic activity of BAC20SNPs + antibiotics against MDR-SA9 ranged from 5.0 to 31 $\mathrm{mm}$. BAC20 + chlortetracycline had the highest antagonistic potential, while BAC20-SNPs + colistin had the lowest activity. The synergistic effect of the SNPs and the antibiotics against the MDRSA18 is shown in Figure 8B. The antagonistic activity against MDR-SA18 ranged from 2.0 to $18 \mathrm{~mm}$. Colistin had the lowest activity, while gentamicin had the highest activity against MDR-SA18.

The antagonistic activity of BAC1 SNPs + the antibiotics against MDR-SA18 ranged from 9.0 to $20 \mathrm{~mm}$, showing a high susceptibility. MDR-SA18 had the highest susceptibility to BAC1 SNPs + ciprofloxacin, while the least susceptibility was to BAC1 SNPs + colistin.

BAC7 SNPs + antibiotics had antibacterial activity ranging from 10 to $24 \mathrm{~mm}$ against MDR-SA18. BAC7 SNPs + gentamicin have 
the highest activity against MDR-SA9. The antagonistic activity of BAC20 SNPs + antibiotics against MDR-SA18 ranged from 6.0 to $26 \mathrm{~mm}$. BAC20 + erythromycin had the highest antagonistic potential, while BAC20 SNPs + colistin had the lowest.

The antagonistic potential of the combined BAC1- SNPs and the antibiotics against MRDSA9 and MDRS18 is shown in

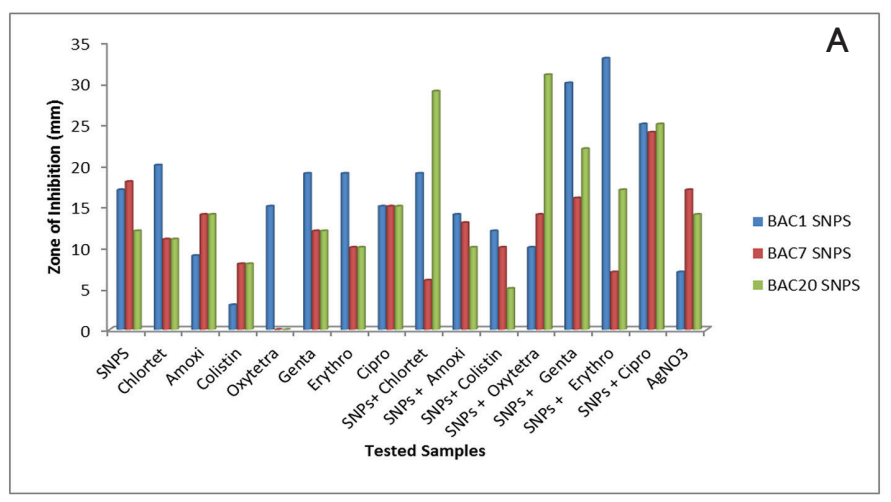

Figure 8A. Diameter of zones of inhibition in $(\mathrm{mm})$ of the of the SNPs, antibiotic and combination of SNPs + antibiotics against the MDR-SA9

SNPs: Silver nanoparticles, MDR: Multidrug resistant, $\mathrm{AgNO}_{3}$ : Silver nitrate, BAC1: Bacillus subtilis, BAC7: B. licheniformis, BAC20: Bacillus subtilis

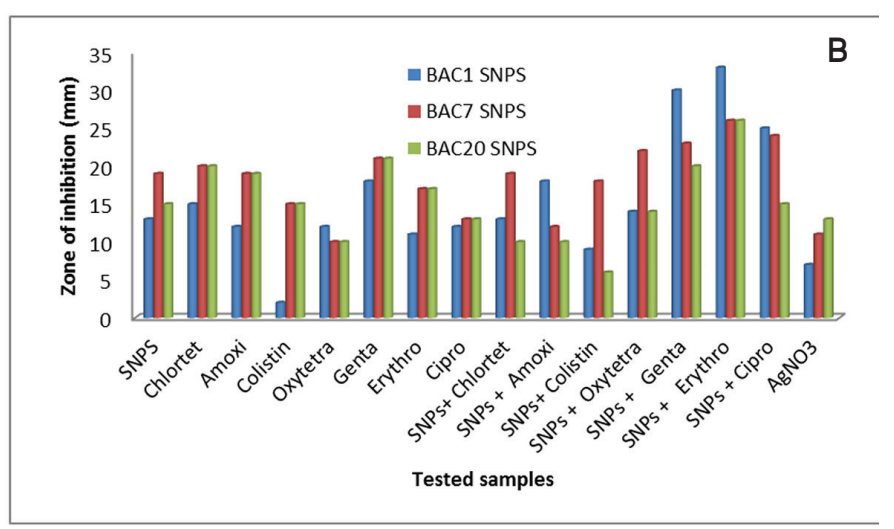

Figure 8B. Diameter of zones of inhibition $(\mathrm{mm})$ of the SNPs, antibiotic and combination of SNPs + antibiotics against the MDR-SA18

SNPs: Silver nanoparticles, MDR: Multidrug resistant, $\mathrm{AgNO}_{3}$ : Silver nitrate, BAC1: Bacillus subtilis, BAC7: B. licheniformis, BAC20: Bacillus subtilis
Tables $4 \mathrm{a}$ and $4 \mathrm{~b}$. The antagonistic activity against MRDSA9 and MRDSA18 was $3.0-33 \mathrm{~mm}$ and $2.0-20 \mathrm{~mm}$, respectively. MRDSA9 was highly susceptible to BAC1-SNPs + erythromycin. It was found that the SNPs produced from Bacillus spp. enhanced the reaction rates of the antibiotics in a synergistic mode as well as in its own way on these pathogens. In the cases of both Salmonella spp. (SA9) and Salmonella enterica subsp. enterica (SA18) the highest $\mathrm{ZOI}$ was produced by the combination of antibiotics + SNPs. This result is in agreement with the findings reported by Krishna et al. ${ }^{48}$ who mentioned increasing efficacies (percentage) of antibiotics like streptomycin and ceftriaxone when used in combination with SNPs against Bacillus subtilis, S. aureus, E. coli, and Proteus vulgaris.

Shahnaz et al..$^{49}$ reported that in vitro antibacterial activity of SNPs synthesized from Penicillium species was obtained in combination with the antibiotics sparfloxacin and ofloxacin against the clinically isolated pathogens Staphylococcus aureus, Bacillus cereus, E. coli, and Proteus vulgaris. It was found that the SNPs produced by Penicillium species enhanced the reaction rates of the antibiotics in a synergistic mode on the clinically isolated pathogens.

The MIC was defined as the lowest concentration of the SNPs that can have an antimicrobial effect on the test organisms. For the MIC evaluation $10 \mathrm{mM}$ was used to prepare different concentrations of the SNPs and different MICs were recorded for the two (MDR) Salmonella spp. Balashanmugam et al. ${ }^{30}$ also reported the MIC of SNPs after testing on some pathogens, with Escherichia coli and Bacillus subtilis having the highest values.

\section{CONCLUSION}

The bioactive metabolites from Bacillus spp. had antibacterial activity against the selected MDR Salmonella spp. The bioactive metabolites were able to bioreduce $\mathrm{AgNO}_{3}$ for SNP biosynthesis. These biologically synthesized SNPs exhibited good antibacterial activity and the combination of SNPs with some antibiotics equally enhanced the antibacterial potential of the antibiotics against the tested isolates. Thus, these nanoparticles can be used as antibacterial agents alone or in combination with antibiotics to improve their antibacterial potential.

Table 4b. Antimicrobial potential of silver nanoparticles biosynthesized using different concentrations of silver nitrate against multidrug resistant-SA18 at different incubation times

Zone of inhibition $(\mathrm{mm}) /$ Incubation time $(\mathrm{h})$ against MDRSA18

\begin{tabular}{|c|c|c|c|c|c|c|c|c|c|}
\hline \multirow{2}{*}{$\begin{array}{l}\text { Concentrations of } \\
\mathrm{AgNO}_{3}\end{array}$} & \multicolumn{3}{|c|}{ BAC1-SNPs } & \multicolumn{3}{|c|}{ BAC7-SNPs } & \multicolumn{3}{|c|}{ BAC20-SNPs } \\
\hline & $24 \mathrm{~h}$ & $48 \mathrm{~h}$ & $72 \mathrm{~h}$ & $24 \mathrm{~h}$ & $48 \mathrm{~h}$ & $72 \mathrm{~h}$ & $24 \mathrm{~h}$ & $48 \mathrm{~h}$ & $72 \mathrm{~h}$ \\
\hline $2 \mathrm{mM}$ & $3.0 \pm 0.0^{d}$ & $4.0 \pm 0.3^{c}$ & $0.0 \pm 0.0^{e}$ & $4.0 \pm 1.0^{c}$ & $4.0 \pm 1.0^{c}$ & $7.0 \pm 0.2^{\mathrm{a}}$ & $0.0 \pm 0.0^{e}$ & $6.0 \pm 0.0^{b}$ & $0.0 \pm 0.0^{e}$ \\
\hline $4 \mathrm{mM}$ & $5.0 \pm 0.5^{c}$ & $0.0 \pm 0.0^{f}$ & $5.0 \pm 0.0^{c}$ & $2.0 \pm 0.6^{\mathrm{e}}$ & $3.0 \pm 0.0^{d}$ & $9.0 \pm 0.4^{b}$ & $10.0 \pm 0.0^{a}$ & $10.0 \pm 0.2^{a}$ & $9.0 \pm 0.0^{b}$ \\
\hline $6 \mathrm{mM}$ & $0.0 \pm 0.0^{e}$ & $10.0 \pm 1.0^{b}$ & $12.0 \pm 1.0^{\mathrm{a}}$ & $0.0 \pm 0.0^{e}$ & $8.0 \pm 0.5^{c}$ & $10.0 \pm 0.5^{b}$ & $2.0 \pm 1.0^{d}$ & $0.0 \pm 0.0^{e}$ & $0.0 \pm 0.0^{\mathrm{e}}$ \\
\hline $8 \mathrm{mM}$ & $7.0 \pm 0.10^{e}$ & $12.0 \pm 0.2^{\mathrm{a}}$ & $9.0 \pm 0.45^{c}$ & $8.0 \pm 1.0^{d}$ & $4.0 \pm 0.1^{f}$ & $4.0 \pm 0.1^{e}$ & $8.0 \pm 0.3^{d}$ & $12.0 \pm 0.0^{\mathrm{a}}$ & $10.0 \pm 1.0^{b}$ \\
\hline $10 \mathrm{mM}$ & $13.0 \pm 0.6^{\mathrm{e}}$ & $15.0 \pm 0.0^{c}$ & $14.0 \pm 1.0^{d}$ & $3.0 \pm 0.0^{\mathrm{h}}$ & $12.0 \pm 1.0^{f}$ & $17.0 \pm 0.0^{b}$ & $8.0 \pm 1.0^{\mathrm{g}}$ & $12.0 \pm 0.0^{f}$ & $21.0 \pm 0.3^{2}$ \\
\hline
\end{tabular}

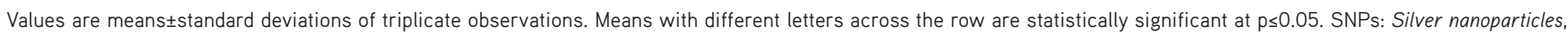

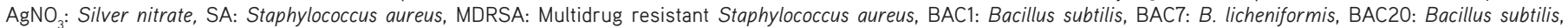
$\mathrm{a}, \mathrm{b}, \mathrm{c}, \mathrm{d}, \mathrm{e}, \mathrm{f}, \mathrm{g}$ : Are statistically significant letters from Duncan multiple range test 
Conflicts of interest: No conflict of interest was declared by the authors. The authors alone are responsible for the content and writing of the paper.

\section{REFERENCES}

1. Oveisi H, Rahighi S, Jiang X, Agawa Y, Beitollahi A, Soichi W, Yusuke $Y$. Improved inactivation effect of bacteria: Fabrication of mesoporous anatase films with fine $\mathrm{Ag}$ nanoparticles prepared by coaxial vacuum Arc deposition. Chem Lett. 2001;40:420-422.

2. Thabit A, Crandon J, Nicolau D. Antimicrobial resistance: impact on clinical and economic outcomes and the need for new antimicrobials. Exp Opin Pharmacother. 2015;16:159-177.

3. Maisonneuve E, Gerdes K. Molecular mechanisms underlying bacterial persisters. Cell. 2014;157:539-548.

4. Ferri M, Ranucci E, Romagnoli P, Giaccone V. Antimicrobial resistance: A global emerging threat to public health systems. Crit Rev Fd Sci Nutr. $2015 ; 2857-2876$.

5. Montville TJ, Matthews KR. Food microbiology: an introduction. $2^{\text {nd }}$ ed. Washington; United States of America: ASM Press; 2008.

6. Pui CF, Wong WC, Chai LC, Nillian E, Ghazali FM, Cheah YK, Nakaguchi Y, Nishibuchi M, Radu S. Simultaneous detection of Salmonella spp., Salmonella typhi and Salmonella typhimurium in sliced fruits using multiplex PCR. Fd Contr. 2011;22:337-342.

7. Butt T, Ahmad RN, Mahmood A, Zaidi S. Ciprofloxacin treatment failure in typhoid fever case, Pakistan. Emerg Infectious Dis. 2003;9:1621-1622.

8. Adabara N, Ezugwu BU, Momojimoh A, Madzu A, Hashiimu Z, Damisa D. The prevalence and antibiotic susceptibility pattern of Salmonella typhi among Patients Attending a Military Hospital in Minna, Nigeria. Adv Prev Med. 2012;2012:875419.

9. Schaffer B, Hohenester U, Trugler A, Hofer F. High-resolution surface plasmon imaging of gold nanoparticles by energy-filtered transmission electron microscopy. Physical Rev. 2009;79:1-10.

10. Service ER. Foodborne Illness Cost Calculator: Salmonella. Washington, D.C; United States Department of Agriculture; 2009.

11. Morikawa M, Ito M, Imanaka T. Isolation of a new surfactin producer Bacillus pumilus A-1, and cloning and nucleotide sequence of the regulator gene, psf-1. J Ferment Bioeng. 1992;74:255-261.

12. Perez C, Suarez C, Castro GR. Production of antimicrobials by Bacillus subtilis MIR 15. J Biotechnol. 1992;26:331-336.

13. Perez C, Suarez C, Castro GR. Antimicrobial activity determined in strains of Bacillus circulans cluster. Folia Microbiol. 1993;38:25-28.

14. Drablos F, Nicholson D, Ronning M. EXAFS study of zinc coordination in Bacitracin A. Biochim Biophys Acta. 1999;1431:433-442.

15. Milner JL, Raffel SJ, Lethbridge BJ, Handelsman J. Culture conditions that influence accumulation of zwittermicin a by Bacillus cereus UW85. Appl Microbiol Biotechnol. 1995;43:685-691.

16. Steller S, Vollenbroich D, Leenders F, Stein T, Conrad B, Hofemeisterr J, Jaques $\mathrm{P}$, Thonart $\mathrm{P}$, Vater J. Structural and functional organization of the fengycin synthease multienzyme system from Bacillus subtilis b213 and A1/3. Chem Biol. 1999;6:31-41.

17. Galvez A, Maqueda M, Cordovilla P, Martinez-Bueno M, Lebbadi M, Valdivia E. Characterization and biological activitiy against Naegleria fowleri of amonebicins produced by Bacillus licheniformis D-13. Antimicrob. Agents Chemother. 1994;38:1314-1319.
18. Leifert C, Li H, Chidburee S, Hampson S, Workman S, Sigee D. Antibiotic production and biocontrol activity by Bacillus subtilis CL27 and Bacillus pumilus CL45. J Appl Bacteriol. 1995;78:97-108.

19. Paulraj K, Seung Taik L. Synthesis and structural characterization of silver nanoparticles using bacterial exopolysaccharide and its antimicrobial activity against food and multi-drug resistant pathogens. Process Biochem. 2013;48:1099-1106.

20. Castellano JJ, Shafii SM, Ko F, Donate G, Wright TE, Mannari RJ, Payne WG, Smith DJ. Comparative evaluation of silver-containing antimicrobial dressings and drugs. Intern Wound J. 2007;4:14-22.

21. Kim JS, Kuk E, Yu KN, Kim J, Park SJ, Lee HJ, Kim SH, Park YK, Park YH, Hwang C, Kim Y, Lee Y, Jeong DH, Cho M. Antimicrobial effects of silver nanoparticles. Nanomed. Nanotechnol. Biol Med. 2007;3:95-101.

22. Morone JR, Elechiguerra JL, Camacho A, Holt K, Kouri JB, Ramirez JT. The bactericidal characterization of silver nanoparticles. Nanotechnol. 2005; 16:2340-2353.

23. Sondi I, Salopek-Sondi B. Silver nanoparticles as antimicrobial agent: a case study on E. coli as a model for Gram-negative bacteria. J Colloid Interface Sci. 2004;275:177-182.

24. Rai M, Yadav A, Gade A. Silver nanoparticles as a new generation of antimicrobials. Biotechnol. Adv. 2009;27:76-83.

25. Lim HK, Asharani PV, Hande MP. Enhanced genotoxi- city of silver nanoparticles in DNA repair deficient mammalian cells. Front Genet. 2012;3:1-13.

26. Stevanovic MM, Skapin SD, Bracko I, Milenkovic M, Petkovic J, Filipic M. Poly (lactide-co-glycolide)/silver nanoparticles: synthesis, characterization, antimicrobial activity, cytotoxicity assessment and ROSinducingpotential. Polymer. 2012;53:2818-2828.

27. Karthik R, Nanasivayam S, Gnanendra KE, Reepika R. Synthesis of silver nanoparticles by $L$. acidophilus 01 strain and evaluation of its in vitro genomic DNA toxicity. Nano-micro Let. 2010;2:160-163.

28. Mandal D, Bolander ME, Mukhopadhyay D, Sarkar G, Mukherjee P. Appl Microbiol Biotechnol. 2006;69:485.

29. Singh D, Rathod V, Ninganagouda S, Herimath J, Kulkarni P. Biosynthesis of silver nanoparticle by endophytic fungi Penicillium sp. isolated from Curcuma longa (turmeric) and its antibacterial activity against pathogenic gram negative bacteria. J Pharm Res. 2013;7:448-453.

30. Balashanmugam P, Santhosh S, Giyaullah H, Balakumaran MD, Kalaichelvan PT. Mycosynthesis, characterization and antibacterial activity of silver nanoparticles from Microporus xanthopus: a macro mushroom. International J Innova Res Sci Engr Technol. 2013;2:1-9.

31. Cappuccino JG, Sherman N. A Laboratory Manual in General Microbiology, $3^{\text {th }}$ ed. California; Benjamin Commius Publication Company Inc; 1996.

32. Riley MA, Wertz JE. Bacteriocins: evolution, ecology, and application. Annu Rev Microbiol. 2002;56:117-137.

33. Kalishwaralal K, Deepak V, Ram Kumar Pandian S, Gurunathan S. Biosynthesis of gold nanocubes from Bacillus lichemiformis. Biores Technol. 2009;100:5356-5358.

34. Kanmani P, Lim ST. Synthesis and structural characterization of silver nanoparticles using bacterial exopolysaccharide and its antimicrobial activity against food and multidrug resistant pathogens. Process Biochem. 2013;48: 1099-1106.

35. El-Batal A, Amin M, Shehata M, Hallol M. Synthesis of silver nanoparticles by Bacillus stearothermophilus using gamma radiation and their antimicrobial activity. World Appl Sci J. 2012;22:1-16. 
36. Valencia GA, Vercik LC, Ferrari R, Vercik A. Synthesis and characterization of silver nanoparticles using water-soluble starch and its antibacterial activity on Staphylococcus aureus. Starch/Stärke, 2013;65:1-7.

37. Schaffer B, Hohenester U, Trugler A, Hofer F. High-resolution surface plasmon imaging of gold nanoparticles by energy-filtered transmission electron microscopy. Physical Rev. 2009;79:1-10.

38. Sadowski Z, Maliszewska IH, Grochowalska B, Polowczyk I, Koźlecki T. Synthesis of silver nanoparticles using microorganisms. Mater Sci Poland. 2008; 26:419-424.

39. Gardea-Torresday LJ, Gomez E, Peratta-Videa RJ, Persons GJ, Troiani $H$, Jose- Yacaman M. Alfalfa sprouts: a natural source for synthesis of silver nanoparticles. Langmuir. 2003;19:1357-1361.

40. Vithiya K, Kumar R, Sen S. Bacillus spp. Mediated extracellular synthesis of silver nanoparticles. Inter J Pharm Pharmaceut Sci. 2014;6:3.

41. Guzman M, Dille J, Godet S. Synthesis and antibacterial activity of silver nanoparticles against Gram-positive and Gram-negative bacteria. Nanomed Nanotechnol Biol Med. 2012;8:35-45.

42. Sharma VK, Yngard RA, Lin Y. Silver nanoparticles: Green synthesis and their antimicrobial activities. Adv Colloid Interf Sci. 2009;145:83-96.

43. Dhanalakshmi T, Rajendran S. Synthesis of silver nanoparticles using Tridax procumbens and its antimicrobial activity. Arch Appl Sci Res. 2012;4:1289-1293.
44. Natarajan K, Selvaraj S. Green synthesis of silver nanoparticles using Bacillus subtilis $1 \mathrm{~A} 751$ and its antimicrobial activity. Res J Nanosci Nanotechnol. 2011;10:1-8.

45. Amin M, Anwar F, Janjua MR, Iqbal MA, Rashid U. Green Synthesis of Silver Nanoparticles through Reduction with Solanum xanthocarpum L. Berry Extract: Characterization, Antimicrobial and Urease Inhibitory Activities against Helicobacter pylori. Intern J Molecu Sci. 2012;13:99239941.

46. Annadurai G, Vanaja M. Coleus aromaticus leaf extract mediated synthesis of silver nanoparticles and its bactericidal activity. Appl Nanosci. 2013;3:217-223.

47. Goldie O, Sunil P, Ashmi M, Golap K, Madhuri S. Facile biosynthesis of gold nanoparticles exploiting optimum $\mathrm{pH}$ and temperature of fresh water algae Chlorella pyrenoidusa. Adv Appl Sci. 2012;3:1405-1412.

48. Krishna G, Kumar SS, Pranitha V, Alha M, Charaya S. Biogenic Synthesis of Silver Nanoparticles and their Synergistic Effect with Antibiotics: A Study against Salmonella Sp. International J Pharmaceu Sci. 2015;7:1-5.

49. Shahnaz M, Anima N, Kathirvel T. Evaluation of antimicrobial activity of biologically synthesized silver nanoparticles from filamentous fungi. Intern. J Pharm Tech Res. 2014;6:1049-1053. 